\title{
INDOLEACETIC ACID PRODUCTION AND CHROMIUM REDUCTION BY CYANOBACTERIA SYNECHOCYSTIS SP. P2A (CHROOCOCCALES) IMMOBILIZED IN ALGINATE BEADS
}

\author{
PRODUÇÃO DE ÁCIDO INDOLACÉTICO E REDUÇÃO DO CROMO POR \\ CIANOBACTÉRIAS Synechocystis SP. P2A (CHROOCOCCALES) IMOBILIZADAS \\ EM ESFERAS DE ALGINATO
}

\author{
Sana KHURSHID ${ }^{1,2}$; Chand ZAHID ${ }^{1}$; Shahida HASNAIN ${ }^{1}$ \\ 1. Department of Microbiology and Molecular genetics, University of the Punjab, Quaid-e-Azam Campus, Lahore 54590, Pakistan; \\ 2. Institute of Molecular Biology and Biotechnology, University of Lahore, Defense road, Lahore, Pakistan; \\ sanakhurshid_7@yahoo.com
}

\begin{abstract}
A simple extrusion method was used to entrap Synechocystis sp.P2A in alginate beads. The viability, growth response and Indoleacetic acid (IAA) production at different $\mathrm{pH}$ were studied in alginate immobilized Synechocystis sp.P2A. $2.6 \%$ sodium alginate (w/v) and $\mathrm{pH}-7$ was found to be optimum for growth of Synechocystis sp. P2A as well as IAA production $(79 \mu \mathrm{g} / \mathrm{ml})$. To prepare effective formulation for plant inoculation, alginate beads were further modified by coating with chitosan or chitosan-polyethylene glycol. Effect of all formulations containing Synechocystis sp. P2A in free and immobilized form on growth of Triticumaestivum was evaluated. Soil inoculation of entrapped Synechocystis in alginate beads coated with chitosan resulted in $20 \%$ increase in root length and $14 \%$ increase in dry weight as compared to non-inoculated seedlings. Free and immobilized cyanobacteria were allowed to grow in BG11 medium supplemented with $100 \mu \mathrm{g} / \mathrm{ml} \mathrm{K}_{2} \mathrm{CrO}_{4}$ and chromium reduction was measured at variable $\mathrm{pH}$. At $\mathrm{pH} 7$ immobilized showed 5\% more reduction than free form. The current study showed that alginate immobilized Synechocystis sp. P2A can accomplish viable functions including plant growth promoting hormone production and chromium reduction and therefore propose an efficient and convenient method for storage and use of cyanobacteria.
\end{abstract}

KEYWORDS. Immobilization. Chitosan. Cyanobacteria. Auxin. Synechocystis

\section{INTRODUCTION}

Cyanobacteria also known as blue green algae are oxygenic phototropic prokaryotes. Cyanobacteria require vary simple growth requirements, which enables them to live in extreme environments, and resist a number of abiotic and biotic stresses. In Proterozoic Eon (2500-543 million years ago) cyanobacteria were principle primary producers, capable of oxygen production as well as nitrogen fixation (KNOLL, 2008). These are capable of producing bioactive compounds, which not only promote their survival but also exploit by other organisms. Cyanobacteria add organic material to soil and excrete plant growth promoting substances like auxin (MOLNAR; ORDOG, 2005; MANICKAVELU et al., 2006) cytokines (HUSSAIN; HASNAIN, 2011). Indoleacetic acid (IAA) is the first auxin isolated and known for its ability to induce stem elongation and root initiation (ARTECA, 1996). Use of photosynthetic bacteria as biofertilizer offers other advantages like they do not contaminate ground water as compared to bacteria. These do not deplete the resources and work in harmony with nature (KANNAIYAN et al., 1997). Survival of cells in soil after inoculation and availability of easy to use formulations are two major limitations in expansion of use of cyanobacteria in agronomy. One way to overcome these problems is the use of alginate based carriers. These formulations encapsulate the living cells, protect the microorganisms against many environmental stresses and release them to the soil gradually when soil microorganisms degrade the polymers. The main advantages of alginate preparations are their non-toxic nature, degradation in the soil, their slow release of microorganisms into the soil and almost unlimited shelf life. Inoculation of alginate beads containing plant growth promoting bacteria have shown to improved plant growth (BASHAN et al., 2002; WU et al., 2011). Chromium is present in various states in our environment, each with different properties. In surface water hexavalent chromium is mostly emitted from industrial effluents. Chromium VI is carcinogenic and genotoxic at high concentrations (GODET et al., 1996). Chromium VI may be reduced chromium III naturally if a large quantity of organic matter is present. ChromiumIII, thermodynamically the most stable state, is either adsorbed on the particulate matter or form large, insoluble polynucleate complexes (SANTONEN, 
Indoleacetic acid...

2009). Unfortunately, this process is rather slow and depends on the appropriate environment. Numerous microorganisms have the special capability to adapt and colonize the metal polluted environments by evolving mechanisms to combat metal toxicity like metal eflux channels, metal resistance plasmids, adsorption uptake and metal biotransformation (RAMI'REZ-DIAZ et al., 2008). Synechocystis sp. $\mathrm{P} 2 \mathrm{~A}$, unicellular cyanobacteria isolated from industrial wastewater is resistant to $100 \mu \mathrm{g} / \mathrm{ml}$ $\mathrm{K}_{2} \mathrm{CrO}_{4}$ (HAMEED; HASNAIN, 2005). The main objective of this study was to evaluate alginate beads suitable to allow the growth of the unicellular cyanobacteria Synechocystis sp. P2A for reduction of chromium and production of IAA, with the ultimate goal of transferring capsules to the field. In this study viability and IAA production of Synechocystis sp. P2A in four different formulations, alginate beads, alginate chitosan beads, alginate chitosan PEG beads and liquid medium at different $\mathrm{pH}$ was evaluated. The efficiency of immobilized Synechocystis sp. P2A as biofertilizer was evaluated through soil inoculation using wheat as test plant. On the other hand, Cr (VI) reduction capacity of immobilized Synechocystis sp. $\mathrm{P} 2 \mathrm{~A}$ was also accessed at different $\mathrm{pH}$.

\section{MATERIALS AND METHODS}

\section{Cyanobcterial strain growth conditions}

Synechocystis sp. [AHZ-HB-P2A] was used in all experiments already isolated from a local environment in Pakistan (HAMEED; HASNAIN, 2005). Cyanobacteria culture was maintained in BG11 liquid medium (RIPPKA et al., 1979) at $25^{\circ} \mathrm{C}$ under continuous fluorescent illumination (5.8 to 7.8 $\left.\mu \mathrm{E} / \mathrm{m}^{2} \mathrm{~s}\right)$.

\section{Producing Alginate beads by simple extrusion method}

Cyanobacteria entrapment within alginatebeads was carried out under sterile conditions. Sodium alginate solution was prepared by dissolving in water with constant stirring, autoclaved for $20 \mathrm{~min}$ at $121{ }^{\circ} \mathrm{C}$. Fifteen days old Synechocystis sp. P2A culture, grown in BG11 liquid medium was concentrated using centrifugation $(5 \mathrm{~min}, 8,000 \mathrm{Xg})$, and then mixed homogeneously into the sodium alginate solution. The mixture was added drop-wise with the aid of 10 $\mathrm{ml}$ sterile syringe into sterilized $1.4 \%(\mathrm{w} / \mathrm{v}) \mathrm{CaCl}_{2}$ at room temperature, and beads immediately formed in the $\mathrm{CaCl}_{2}$ solution.

\section{Optimization of entrapment of cyanobacteria}

KHURSHID, S. ZAHID, C. HASNAIN, S.

Six concentrations $(\mathrm{w} / \mathrm{v})$ of sodium alginate $1.2 \%, 1.6 \%, 2.2 \%, 2.6 \%, 3 \%$ and $3.4 \%$ were prepared separately. Beads containing cells were prepared by simple extrusion method. Then beads were washed three times in sterile water and transferred to BG11 medium supplemented with 1.5 g/L tryptophan (HUSSAIN; HASNAIN, 2011). Entrapped bacteria were allowed to grow at $25{ }^{\circ} \mathrm{C}$ under continuous fluorescent illumination (5.8 - 7.8 $\left.\mu \mathrm{E} / \mathrm{m}^{2} \mathrm{~s}\right)$. Mechanical properties like weight and size of alginate beads were observed regularly.

\section{Solubility of beads and viable population}

Beads were solubilized for bacterial count by immersing one bead per $\mathrm{ml}$ of potassium phosphate buffer, for 40-60 min. To facilitate the solubility, the beads were vigorously shaken on a Vortex mixer. After solubilization the suspended cells were serially diluted in sterile normal saline and suitable dilutions were spreaded on BG11 plates in duplicate. Plates were incubated at $25{ }^{\circ} \mathrm{C}$. After 15 days, number of colonies on each plate was counted and CFU/ml was calculated.

\section{Quantification of IAA Production}

At every third day $1.5 \mathrm{ml}$ of medium containing beads was removed and centrifuged $(8,000 \mathrm{Xg} 10 \mathrm{~min})$. IAA was detected in $1 \mathrm{ml}$ of supernatant using Salkowski reagent (TANG; BORNER, 1979). A standard curve was drawn for comparison to determine IAA concentration.

\section{Alginate beads coating}

Two different coats to cover cyanobacteria containing alginate beads were designed; Chitosan alone and chitosan containing Polyethylene glycol (PEG). $2.6 \% \quad(\mathrm{w} / \mathrm{v})$ alginate beads with Synechocystis P2A cells, were immersed in $0.4 \%$ (w/v) sterilized chitosan solution alone or $0.4 \%$ chitosan containing $0.1 \%$ (v/v) Polyethylene glycol and stirred. After $45 \mathrm{~min}$, chitosan solution was removed and beads were washed with sterile distilled water. Cyanobacterial growth and indole aceticacid production in coated beads was monitored for two weeks in BG11 medium.

\section{Storage}

Two different approaches were used: drying and dark storage. For drying $10 \%$ sucrose or $10 \%$ lactose were used as protective agent. Beads were immersed in sterilized solution of protective medium and kept for one hour at $25^{\circ} \mathrm{C}$. Recovered were then placed on filter paper in sterilized plate and dried at $30^{\circ} \mathrm{C}$ for 48 hours. After two days dried beads collected and stored at room temperature in 
hermetically sealed containers. In second procedure, alginate beads were stored in distilled water in dark at $4^{0} \mathrm{C}$. The same procedures of measuring the cells in fresh beads were performed for the stored beads.

\section{Pot experiment}

Seeds of wheat (Triticum aestivum) were surface sterilized with $0.1 \% \mathrm{HgCl}_{2}$ then washed with distilled water. Experiment consists of following treatments: Free cyanobacterial cells inoculated (A); Immobilized cyanobacterial cells in alginate beads inoculated (B1); Inoculation of cyanobacteria cells in chitosan coated alginate beads (B2); Inoculation of cyanobacterial cells entrapped in chitosan PEG coated beads (B3); each treatment received $1 \times 10^{12}$ free or alginate-entrapped cells per pot. Control: seeds with no inoculation(C); Blank alginate beads inoculated (F1); Blank chitosan coated alginate beads inoculated (F2); Blank chitosan PEG coated beads inoculated (F3). Each pot received six surface sterilized Wheat seeds. The experiment presented a completely random design with four replications per treatment. Experiment was performed in pots containing $150 \mathrm{~g}$ garden soil in each pot. Plants were kept under control conditions $\left(25^{\circ} \mathrm{C}, 16\right.$ hour \pm 10 Klux light). Pots were observed and watered regularly. Plants were harvested after 15 days and different growth parameters were measured. Plant dry weight was recorded after drying at $80^{\circ} \mathrm{C}$ to constant weight.

\section{Chromium Reduction potential}

Synechocystis sp. P2A in alginate beads and free form were allowed to grow in BG11 medium supplemented with $100 \mu \mathrm{g} / \mathrm{ml} \quad \mathrm{K}_{2} \mathrm{CrO}_{4}$. Diphenylcarbazide method (DELEO; EHRLICH, 1994) was used to measure concentration of remaining chromium at the end of experiment.
KHURSHID, S. ZAHID, C. HASNAIN, S.

Chromium reduction potential was estimated as the concentration difference $\mathrm{Cr}$ (VI) between inoculated cultures and sterile controls. The experiment was done in BG11 medium with pH 6,7 and 8. Bacterial growth was monitored by optical density of medium at $730 \mathrm{~nm}$; beads were first solubilized in potassium phosphate buffer before taking Optical density.

\section{Statistical analysis}

All experiments are done at least in duplicate. Results of all repetitions were analyzed together by one-way analysis of variance (ANOVA) at $P \leq 0.05$ using SPSS software (SPSS Inc., Chicago IL).

\section{RESULTS}

\section{Entrapment of Synechocystis in alginate beads}

Cyanobacteria Synechocystis sp. P2A was immobilized in form of alginate beads using six different concentrations (w/v) of sodium alginate, ranging $1.2 \%$ to $3.4 \%$. Successful entrapment of cyanobacteria was achieved and cells remained viable during encapsulation and multiplied inside beads. Color of bead turned dark green after five days of incubation due to growth of cyanobacteria. To verify presence of unicellular cyanobacteria; a single bead after ten days of growth was sliced on the glass slide and observe under microscope. Beads with less concentration of alginate were smaller in size but more fragile. Viability and multiplication of cyanobacterial cells were checked by taking CFU/bead at every third day (Fig. 1). Bacterial growth continued to increase within alginate beads for fifteen days in BG11 medium. It was observed that after fifteen days of incubation in medium beads became very fragile and even release of cells in growth medium from beads if continued to grow.

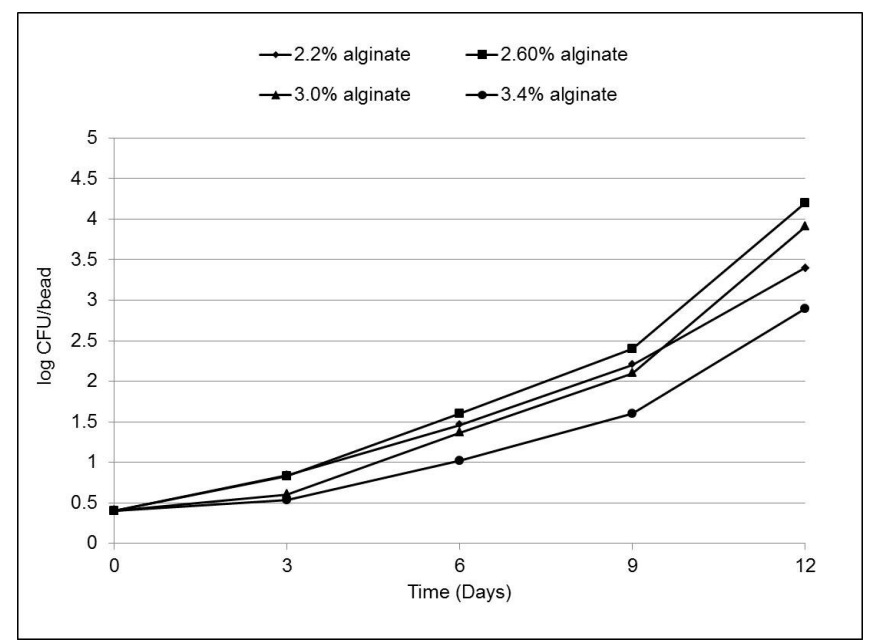

Figure 1. Growth response of entrapped Synechocystis cells in beads of different alginate w/v percentage, showing a gradual increase in CFU/bead with time 
Although all cyanobacterial cells remained viable and multiplied in beads of all alginate concentrations; $2.6 \%$ was selected for further studies as a compromise between algal growth and bead stability. Alginate beads containing Synechocystis P2A can be stored in dry or wet forms for more than six months without the loss of activity.

\section{Indole acetic acid (IAA) production by alginate entrapped cells}

Indole-3-acetic acid is the most important naturally occurring auxin and is implicated in many aspects of plant growth and development
KHURSHID, S. ZAHID, C. HASNAIN, S.

(SPAEPAN et al., 2007; ZHAO, 2010). Release of indoleacetic acid (IAA) and related compounds from entrapped cyanoacterial cells in surrounding medium was successfully detected by colorimetric method. Amount of released IAA was measured every third day of growth (Table 1). The aim was to check any negative effect on production and release of IAA by entrapped Synechocystis P2A as well as to check stability of bead structure in presence of tryptophan. IAA production increased with the increase of cyanobacterial growth. There was no significant difference of cyanobacterial growth and stability of beads between beads grown in BG11 and that grown in BG11 supplemented with tryptophan.

Table 1. Indoleacetic acid (IAA) release in tryptophan supplemented BG11 medium by Synechocystis sp. P2A

\begin{tabular}{ccccc}
\hline \multirow{2}{*}{$\begin{array}{c}\text { Alginate Conc. } \\
(\%)(w / v)\end{array}$} & IAA concentration $(\mu \mathrm{g} / \mathrm{ml})^{l}$ \\
\cline { 2 - 5 } & Day 3 & Day 6 & Day 9 & Day 13 \\
\hline 2.2 & $11 \pm 0.4$ & $38 \pm 0.0$ & $70 \pm 1.0$ & $85 \pm 0.0$ \\
2.6 & $9 \pm 0.3$ & $37 \pm 1.0$ & $56 \pm 1.0$ & $79 \pm 0.5$ \\
3 & $10.5 \pm 0.5$ & $36.4 \pm 0.2$ & $56 \pm 0.3$ & $72 \pm 0.2$ \\
3.4 & $10 \pm 0.2$ & $15 \pm 0.5$ & $33 \pm 0.5$ & $70 \pm 1.0$ \\
\hline
\end{tabular}

1 Values are mean of two replicates.

\section{IAA production from coated alginate beads}

Alginate beads were treated with different chemicals to prepare capsules. Coating increased the mechanical and chemical stability of beads and prevented cell release in medium. Fig. 2 shows IAA production by alginate beads, chitosan coated and chitosan-PEG coated beads at three different $\mathrm{pH}$. In all formulations maximum production of IAA was at $\mathrm{pH}-7$. IAA release from cells in chitosan coated alginate beads only decreased $18 \%$ and $23 \%$ at $\mathrm{pH} 6$ and 7 respectively; while in free form and in other formulations, there was decrease in IAA production from $7 \%$ to $70 \%$.

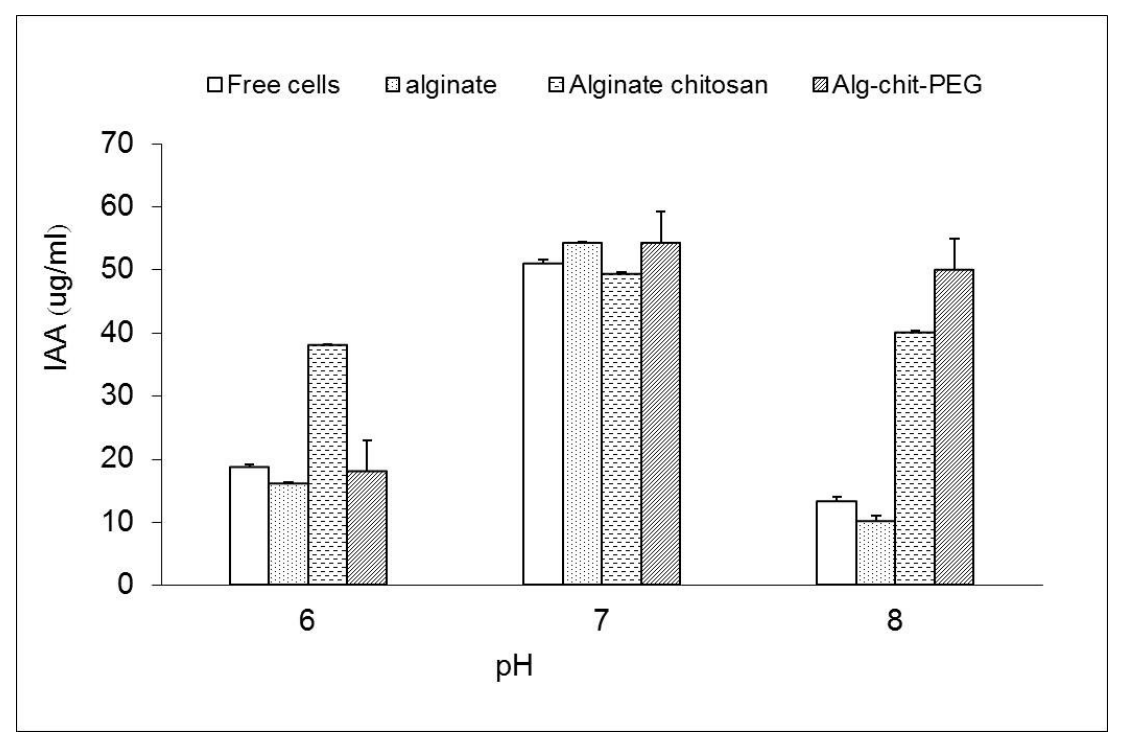

Figure 2. Indoleacetic acid (IAA) production by Synechocystis sp. P2A in four different forms in BG11 medium at $\mathrm{pH} \mathrm{6,7}$ and 8. Values are mean of two replicates. Free cells (White bars); alginate beads cells (dotted bars); alginate chitosan beads with cells (horizontal dashed bars) and alginate chitosan polyethylene glycol beads (lined bar). 


\section{Plant growth experiment}

A pot experiment was performed to study the effect of phytoharmone producing Synechocystis sp. P2A in different formulations on growth of wheat (Triticum aestivum) seeds. Growth parameters of wheat seedlings grown with Synechocystis inoculum in free and in different encapsulated forms are given in Table 2. Empty beads were also inoculated as control to check any negative effect of polymers on plant growth. But no negative effect was noted in any growth parameter. Only Chitosan coated beads and free Synechocystis inoculated plants showed significant increase in shoot length $(\mathrm{P} \leq 0.05)$. Synechocystis $\mathrm{sp}$. P2A has a
KHURSHID, S. ZAHID, C. HASNAIN, S.

significant impact on growth of roots. Chitosan alginate beads with Synechocystis inoculated seedlings showed $20 \%$ increase in root length as compared to non-inoculated plants. Synechocystis in free and other entrapment forms also significantly $(\mathrm{P} \leq 0.05)$ increased root length of inoculated plants. Chitosan alginate and Alginate-chitosan-PEG Synechocystis beads inoculated plants showed $13.9 \%$ and $24 \%$ increase in dry weight as compared to non-inoculated plants. While free Synechocystis sp. P2A inoculated plants did not showed significant increase in dry weight as compared to control $(\mathrm{P} \leq 0.05)$.

Table 2. Effect of Synechocystis sp. P2A in free and immobilized form on shoot length, root length, Number of roots and dry weight of Triticum aestivum Treatment ${ }^{a}$

\begin{tabular}{ccccc}
\hline & $\begin{array}{c}\text { Shoot length } \\
(\mathrm{cm})\end{array}$ & $\begin{array}{c}\text { Root length } \\
(\mathrm{cm})\end{array}$ & No. of Roots & $\begin{array}{c}\text { Dry matter } \\
(\text { mg/plant })\end{array}$ \\
\hline Control & $16.5 \pm 0.28$ & $14.0 \pm 0.47$ & $4.3 \pm 0.47$ & $21.6 \pm 0.39$ \\
B1 & $17.2 \pm 0.16$ & $15.8 \pm 0.32^{*}$ & $5.0 \pm 0.0$ & $22.6 \pm 0.39^{*}$ \\
B2 & $17.7 \pm 0.25^{*}$ & $17.5 \pm 0.22^{*}$ & $5.1 \pm 0.04$ & $24.5 \pm 0.45^{*}$ \\
B3 & $16.5 \pm 0.34$ & $15.9 \pm 0.30^{*}$ & $5.0 \pm 0.0$ & $26.8 \pm 0.45$ \\
A & $20.3 \pm 0.5^{*}$ & $15.6 \pm 0.47$ & $5.0 \pm 0.0$ & $20.8 \pm 0.40$ \\
F1 & $16.5 \pm 0.38$ & $15.0 \pm 0.16$ & $5.0 \pm 0.0$ & $18.6 \pm 0.46$ \\
F2 & $16.7 \pm 0.34$ & $15.8 \pm 0.3^{*}$ & $4.8 \pm 0.2$ & $21.6 \pm 0.41^{*}$ \\
F3 & $17.0 \pm 0.45$ & $15.1 \pm 0.35$ & $4.6 \pm 0.24$ & $22.1 \pm 0.15$ \\
LSD at 0.05 & 1.043 & 1.00 & NS & 1.17 \\
\hline
\end{tabular}

* indicates significantly different from control at $P \leq 0.05$; NS indicates not significant at $P \leq 0.05$

${ }^{a}$ A - free Synechocystis sp. P2A; B1 - alginate beads with Synechocystis sp. P2A; B2 - alginate-chitosan beads with Synechocystis sp. $P 2 A ; B 3$ - alginate-chitosan-PEG beads with Synechocystis sp. P2A; F1 - alginate beads without Synechocystis sp. P2A; F2 - alginatechitosan beads without Synechocystis sp. P2A; F3 - alginate-chitosan-PEG without Synechocystis sp. P2A

\section{Chromium reduction.}

Chromium (VI) reduction potential of Synechocystis sp. P2A in free and immobilized form was measured at three different pH. $100 \mu \mathrm{g} / \mathrm{ml}$ $\mathrm{K}_{2} \mathrm{CrO}_{4}$ was added to media and concentration of hexavalent chromium was detected by diphenylcarbazide method. Diphenylcarbazide specifically bind to chromium (VI) and purple colors develop. Chromium (VI) concentration in medium gradually decreased with time. At $\mathrm{pH}-6$ free cells and immobilized cells of Synechocystis showed same level of reduction. $40.8 \%$ reduction by immobilized cells and $40.7 \%$ by free cells. At pH-7 immobilized cells showed more reduction $(59.5 \%)$ as compared to free cells $(54.2 \%)$. At $\mathrm{pH}-8$ immobilized cells showed $44.6 \%$ reduction while free cyanobacteria showed $47.7 \%$ reduction in chromium concentration. Alginate beads without cells were used as control at all $\mathrm{pH}$, but there was no significance reduction by empty beads. In all $\mathrm{pH}$ maximum reduction of chromium carried out by immobilized bacteria at $\mathrm{pH}-7$ (Figure 3). 


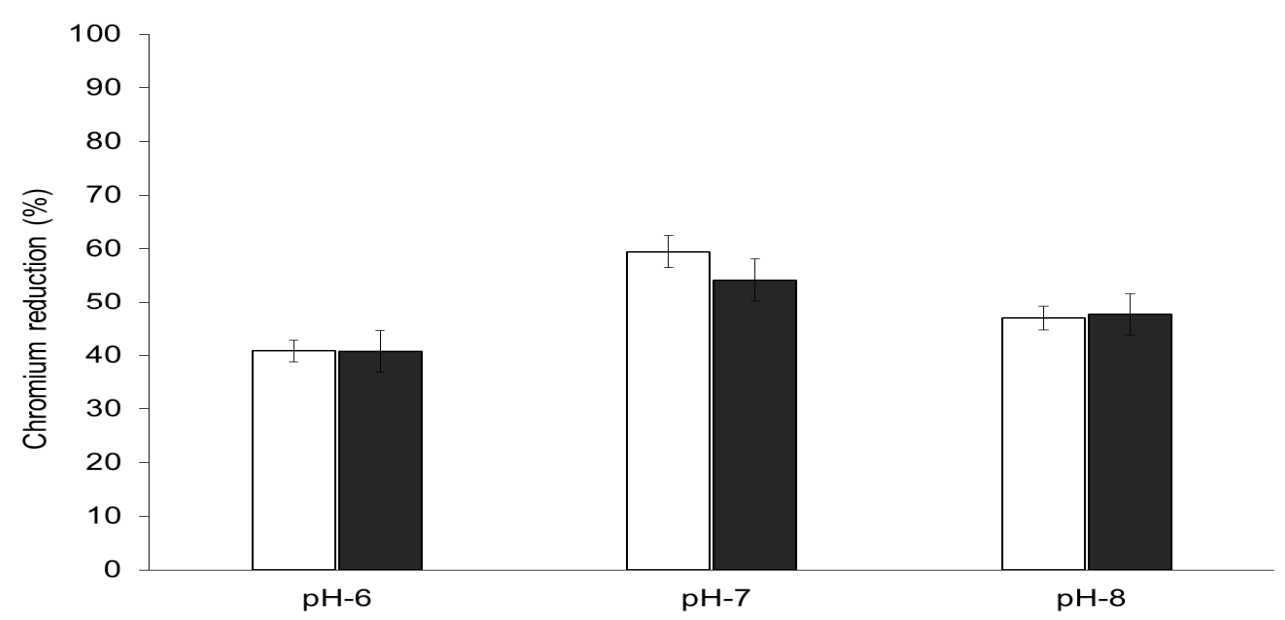

Figure 3. Percentage reduction of $\mathrm{Cr}(\mathrm{VI})$ at $\mathrm{pH} 6,7$ and 8 after 14 days in free form (Black bars) and alginate immobilized form (White bars).

\section{DISCUSSION}

Most root-promoting microorganisms synthesize indole-3-acetic acid (IAA), and their effect on plants mimics that of exogenous IAA. Tryptophan is a precursor for bacterial IAA biosynthesis (ONA et al., 2005); therefore tryptophan was added before inoculation in auxin production medium. Increase in tryptophan concentration increased the amount of IAA release by Synechocystis sp. P2A. Presence of tryptophan also increased growth of cyanobacteria. Sergeeva et al., (2002) proposed two reasons: First, cyanobacteria could directly use exogenous tryptophan and convert it into IAA; second, tryptophan could be used as a source of nitrogen during the initial stages of cultivation to increase growth. No adverse effect of tryptophan on cyanobacterial growth or bead stability was observed. In the rhizosphere tryptophan can originate from two sources: either released from degrading root and microbial cells or released from root exudates (SPAEPEN et al., 2007).

This study showed, use of two polymers alginate and chitosan simultaneously as inoculant carriers for unicellular cyanobacteria. In soil, inoculated cyanobacteria have competition with native bacteria in soil. Therefore they should be greater in number and protected. Alginate beads act as reservoir of inoculated microorganism, where they can multiply and released into the environment. Alginate is a polysaccharide composed of Lguluronic $(\mathrm{G})$ and D-mannuronic acid (M) monomers in varying proportions and sequential arrangements. The gelation takes place due to the interaction of the calcium cations with the alginate
G-blocks (SMIDSROD; SKJAK-BRAEK, 1990). The mechanical properties of gel bead depend strongly on the composition and concentration of the alginate, and on the cation or polycation used as a gel-inducing agent (MOREIRA et al., 2006). But calcium ions can be removed in presence of chelating agents such as phosphate, which results in dissolution of gel beads that is why these are suitable for the soil applications. When an anionic polymer, such as alginate and a cationic polymer, such as chitosan are present simultaneously in an aqueous solution, a polyelectrolyte complex is formed. Chitosan reduces cell release when applied as a membrane coat round a gel coat containing cells (ZHOU et al., 1998). Thus alginate beads and chitosan coated beads provide two types of systems. Alginate beads are easily biodegradable and cells are released in soil in short period. While chitosan coated beads are mechanically strong therefore cells are released slowly in soil, multiplying inside beads simultaneously.

When applied to wheat seeds in pot experiment, double-coated Synechocystis sp. P2A improved growth. Cyanobacterial suspension inoculum improved a number of growth parameters in wheat plants by modifying their endogenous phytohormones (HUSSAIN; HASNAIN, 2011). The production of growth promoting substances by cyanobacteria and their direct growth promoting effect on a rice crop was shown by Kannaiyan et al., (1997). Forvarious plant growth promoting rhizobacteria, it has been demonstrated that enhanced root proliferation is related to bacterial IAA biosynthesis. Studies with Azospirillum mutants altered in IAA production support the view that increased rooting is caused by Azospirillum 
Indoleacetic acid...

IAA synthesis (DOBBELAERE et al., 1999). This increased rooting enhances plant mineral uptake and root exudation, which in turn stimulates bacterial colonization and thus amplifies the inoculation effect (DOBBELAERE et al., 1999).

Chitosan alginate and Alginate-chitosanPEG Synechocystis beads inoculated plants showed $13.9 \%$ and $24 \%$ increase in dry weight as compared to non-inoculated plants. While free Synechocystis sp. P2A inoculated plants did not showed significant increase in dry weight as compared to control $(\mathrm{P} \leq 0.05)$. Increased activity of cyanobacteria when inoculated in immobilized form to that of free form could be attributed to several reasons. There are many stresses that bacteria must endure upon transfer to the competitive and often harsh soil environment. In soil inoculation some of cyanobacterial cells may be killed by some other pathogenic bacteria and therefore cannot form association with germinating seeds. Entrapment increases resistance to stresses and reduce loss of bacteria. Cyanobacterial cells also enhanced the plant growth by providing protection against pathogenic microorganisms.

Besides showing plant growth promoting effects, Immobilized Synechocystis sp. P2A also
KHURSHID, S. ZAHID, C. HASNAIN, S.

reduced hexavalent chromium. Chromium compounds are used in many industries and industrial discharges often cause environmental pollution. Soluble hexavalent chromium species $[\mathrm{Cr}$ (VI)] are extremely toxic and exhibit mutagenic and carcinogenic effects on biological systems due to their strong oxidizing nature. Chromate $\left(\mathrm{CrO}_{4}{ }^{2-}\right)$ is the dominant $\mathrm{Cr}$ (VI) species in aqueous environments at $\mathrm{pH} 6.5$ to 9 . Trivalent chromium, $\mathrm{Cr}$ (III), is less soluble and less toxic. Thus, reduction of $\mathrm{Cr}$ (VI) to $\mathrm{Cr}$ (III) represents a potentially useful detoxification process (ISHIBASHI et al., 1990). Synechocystis sp. P2A known to reduce hexavalent chromium retained its ability in alginate chitosan beads. Maximum reduction $(59.5 \%)$ was observed at $\mathrm{pH}-7$ by immobilized cells. Increase uptake of chromium immobilized Aulosirafertilissimain comparison to free cells was reported by Banerjee et al., (2004).

In conclusion, alginate beads containing Synechocystissp. P2A coated with chitosan showed improved plant growth. Entrapment of cyanobacterial cells in alginate chitosan beads could provide a unique and easy method of soil inoculation during sowing of seeds, to improve plant growth.

RESUMO: Um método de extrusão simples foi utilizado para aprisionar Synechocystis sp.P2A em esferas de alginato. A viabilidade, a resposta ao crescimento e a produção de ácido indolacético (IAA) a diferentes pH foram estudadas na Synechocystis sp.P2A imobilizada com alginato. Alginato de sódio a 2,6\% (p/v) e pH-7 revelou-se ótimo para o crescimento de Synechocystis sp. P2A, bem como para a produção de IAA (79 $\mu \mathrm{g} / \mathrm{ml}$ ). Para preparar uma formulação eficaz para inoculação de plantas, as esferas de alginato foram adicionalmente modificadas por revestimento com quitosano ou quitosano-polietileno glicol. O efeito de todas as formulações contendo Synechocystis sp. P2A em forma livre e imobilizada no crescimento de Triticumaestivum foi avaliado. A inoculação no solo com Synechocystis aprisionado em esferas de alginato revestidas com quitosano resultou em um aumento de $20 \%$ no comprimento da raiz e aumento de $14 \%$ no peso seco em comparação com mudas não inoculadas. As cianobactérias livres e imobilizadas foram deixadas crescer em meio BG11 suplementado com $100 \mu \mathrm{g} / \mathrm{ml}$ de $\mathrm{K} 2 \mathrm{CrO} 4$ e a redução do cromo foi medida a um pH variável. A um pH 7 a forma imobilizada apresentou 5\% mais de redução do que a forma livre. O presente estudo mostrou que o alginato imobilizado de Synechocystis sp. P2A pode realizar funções viáveis, incluindo a produção de hormônio promotor do crescimento de plantas e redução de cromo e, portanto, propor um método eficiente e conveniente para armazenamento e uso de cianobactérias.

PALAVRAS-CHAVE: Imobilização. Quitosano. Cianobactérias; Auxina; Synechocystis

\section{REFERENCES}

ARTECA, R. Plant growth substances. New York: Chapman \& Hall, 1996. https://doi.org/10.1007/978-1-47572451-6

BANERJEE, M.; MISHRA, S.; CHATTERJEE, J. Scavenging of nickel and chromium toxicity in Aulosira fertilissima by immobilization: Effect on nitrogen assimilating enzymes. Electronic Journal Of

Biotechnology, v. 7, n. 3, 2004. https://doi.org/10.2225/vol7-issue3-fulltext-9 
BASHAN, Y.; HERNANDEZ, J.; LEYVA, L.; BACILIO, M. Alginate microbeads as inoculant carriers for plant growth-promoting bacteria. Biology And Fertility Of Soils, v. 35, n. 5, p. 359-368, 2002. https://doi.org/10.1007/s00374-002-0481-5

DELEO, P.; EHRLICH, H. Reduction of hexavalent chromium by Pseudomonas fluorescens LB300 in batch and continuous cultures. Applied Microbiology And Biotechnology, v. 40, n. 5, p. 756-759, 1994. https://doi.org/10.1007/BF00173341

DOBBELAERE, S.; CROONENBORGHS, A.; THYS, A.; BROEK, A. V.; VANDERLEYDEN, J. Phytostimulatory effect of Azospirillum brasilense wild type and mutant strains altered in IAA production on wheat. Plant and Soil, v. 212, n. 2, p. 153-162, 1999. https://doi.org/10.1023/A:1004658000815

GODET, F.; BABUT, M.; BURNEL, D.; VEBER, A.; VASSEUR, P. The genotoxicity of iron and chromium in electroplating effluents. Mutation Research/Genetic Toxicology, v. 370, n. 1, p. 19-28, 1996.

HAMEED, A.; HASNAIN, S. Cultural characteristics of chromium resistant unicellular cyanobacteria isolated from local environment in Pakistan. Chinese Journal of Ocean and Limnology, v. 23, n. 4, p. 433-441, 2005. https://doi.org/10.1007/BF02842688

HUSSAIN, A.; HASNAIN, S. Phytostimulation and biofertilization in wheat by cyanobacteria. Journal Of Industrial Microbiology and Biotechnology, v. 38, n. 1, 85-92, 2010. https://doi.org/10.1007/s10295-0100833-3

ISHIBASHI, Y.; CERVANTES, C.; SILVER, S. Chromium reduction in Pseudomonas putida. Applied and Environmental Microbiology, v. 56 n. 7, p. 2268-2270, 1990.

KANNAIYAN, S.; ARUNA, S. J.; KUMARI, S. M. P.; and HALL, D. O. Immobilized cyanobacteria as a biofertilizer for rice crops, Journal of applied phycology, v. 9, n. 2, p. 167-174, 1997.

https://doi.org/10.1023/A:1007962025662

KNOLL, A. H. Cyanobacterial nitrogen fixation in the ocean.Diversity, regulation and ecology. In: HERRERO, A.; FLORES, E. The cyanobacteria. Norfolk: Caister Academic Press, 2008.

MANICKAVELU, A.; NADARAJAN, N.; GANESH, S. K.; RAMALINGAM, R.; RAGURAMAN, S.; GNANAMALAR, R. P. Organogenesis induction in rice callus by cyanobacterial extracellular product. African Journal of Biotechnology, v. 5, n. 5, p. 437, 2006.

MOLNÁR, Z:; ÖRDÖG, V. Microalgal and cyanobacterial extracts in the tissue cultures of higher plants (pea, tobacco, beet). Acta Biologica Szegediensis, v. 49, n. 1-2, p. 39-40, 2005.

MOREIRA, S.; MOREIRA-SANTOS, M.; GUILHERMINO, L.; RIBEIRO, R. Immobilization of the marine microalga Phaeodactylum tricornutum in alginate for in situ experiments: Bead stability and suitability.

Enzyme And Microbial Technology, v. 38, n. 1-2, p. 135-141, 2006.

https://doi.org/10.1016/j.enzmictec.2005.05.005

ONA, O.; IMPE, J.; PRINSEN, E.; VANDERLEYDEN, J. Growth and indole-3-acetic acid biosynthesis of Azospirillum brasilense Sp245 is environmentally controlled. FEMS Microbiology Letters, v. 246 n. 1, p. 125-132, 2005. https://doi.org/10.1016/j.femsle.2005.03.048

RAMÍREZ-DÍAZ, M.; DÍAZ-PÉREZ, C.; Vargas, E.; Riveros-Rosas, H.; Campos-García, J.; Cervantes, C. Mechanisms of bacterial resistance to chromium compounds. Biometals, v. 21, n. 3, p. 321-332, 2007. https://doi.org/10.1007/s10534-007-9121-8 
RIPPKA, R.; DERUELLES, J.; WATERBURY, J.; HERDMAN, M.; STANIER, R. Generic Assignments, Strain Histories and Properties of Pure Cultures of Cyanobacteria. Journal Of General Microbiology, v. 111, n. 1, p. 1-61, (1979). https://doi.org/10.1099/00221287-111-1-1

SANTONEN, T. Inorganic chromium(III) compounds. Geneva: World Health Organization, 2009.

SERGEEVA, E.; LIAIMER, A.; BERGMAN, B. Evidence for production of the phytohormone indole-3-acetic acid by cyanobacteria. Planta, v. 215 n. 2, p. 229-238, 2002. https://doi.org/10.1007/s00425-002-0749-x

SMIDSRØD, O.; SKJA, G. Alginate as immobilization matrix for cells. Trends in biotechnology, v. 8, p. 7178, 1990. https://doi.org/10.1016/0167-7799(90)90139-O

SPAEPEN, S.; VANDERLEYDEN, J; Remans, R. Indole-3-acetic acid in microbial and microorganism-plant signaling. FEMS Microbiology Reviews, v. 31, n. 4, p. 425-448, 2007. https://doi.org/10.1111/j.15746976.2007.00072.x

TANG, W. Y; BORNER, J. Enzymes involved in synthesis and breakdown of indoleacetic acid. In: Modern Methods of Plant Analysis, 7 eds; PAECH, K; TRACEY, M.V, Gohingen, Heidelberg: Springer Verlag, 1979, p. 238-241.

WU, Z.; ZHAO, Y.; KALEEM, I.; LI, C. Preparation of calcium-alginate microcapsuled microbial fertilizer coating Klebsiella oxytoca Rs-5 and its performance under salinity stress. European Journal of Soil Biology, v. 47 n.2, p. 152-159, 2011. https://doi.org/10.1016/j.ejsobi.2010.11.008

ZHAO, Y. Auxin Biosynthesis and Its Role in Plant Development. Annual Review of Plant Biology, v. 61, v. 1, 49-64, 2010.

ZHOU, Y., MARTINS, E., GROBOILLOT, A., CHAMPAGNE, C., \& NEUFELD, R. Spectrophotometric quantification of lactic bacteria in alginate and control of cell release with chitosan coating. Journal of Applied Microbiology, v. 84, n. 3, p. 342-348, 1998. https://doi.org/10.1046/j.1365-2672.1998.00348.x 